\title{
Qualitative Analysis To Reduce Unhealthy Houses on Kerinci District, Indonesia
}

\author{
Yudha Gusti Wibowo ${ }^{1}$, Bimastyaji Surya Ramadan ${ }^{2}$, Dito Anurogo ${ }^{3}$, Oski Illiandri, \\ Muhammad Naswir ${ }^{5}$
}

${ }^{1}$ Postgraduate Student, Postgraduate Program, Universitas Jambi, Jambi - 36122, Indonesia ${ }^{2}$ Lecturer, Department of Environmental Engineering, Universitas Diponegoro, Semarang - 50277, Indonesia.

${ }^{3}$ Medical Faculty, Universitas Muhammadiyah Makasar, Indonesia

${ }^{4}$ Department of Biomedical Sciences, Medical Faculty, Universitas Lambung Mangkurat, Banjarmasin, Indonesia

${ }^{5}$ Professor, Department of Engineering, Universitas Jambi, Jambi, Indonesia Correspondence Email: yudhagustiwibowo26@gmail.com

\begin{abstract}
Healthy houses is a problem on developing countries. This study mainly focus on urban areas and the health effect of poor water and sanitation, floor, inadequate heating, poor food storage and overcrowding. This research has used qualitative method with questionnaires has spread to a hundred and six homes about characteristics of healthy home. The questionnaires have spread to Pondok village and Bukit Kerman village, Kerinci District, Jambi Province, Indonesia. Result showed 90\% houses too dense and 10 no dense, $98 \%$ houses on this area are unhealthy houses and $10 \%$ healthy houses. Unhealthy houses that affected diseases such as $20 \%$ diaarhea, $29 \%$ other diseases, $13 \%$ ARI, $10 \%$ malaria
\end{abstract}


$15 \%$ skin and $12 \%$ no diseases. We recommended to make a public health policy to reducing unhealthy houses on this area.

Keyword: Healthy houses, unhealthy houses, Kerinci, Diseases.

\section{Introduction}

Study of healthy house on developing countries were relatively fewer than developed countries [1]. This study mainly focus on urban areas and the health effect of poor water and sanitation, floor, inadequate heating, poor food storage and overcrowding [2]. Therefore, cultural health beliefs might affect the house design which interfere the local public health [3]. This beliefs make a different situation in each local/traditional houses, especially in developing countries, where the cultural diversity can be found everywhere [4]. Physical environment of traditional houses would affect directly to the people health status [5]. Indigenous environment such as ontological security [6], social status, sense of community and social capital [7] also need to be considered as external factor of health houses.

Massive population growth that occurs on developing countries will increase the needs of housing which potentially increase the number of unhealthy house. Indonesia, as part of developing country, has many unhealthy houses which are caused by the house shape and occupant behavior [8]. People spend approximately $90 \%$ of their time indoor, and 69 percent in their own house [9]. This data inform the need of creating suitable environment on the house. Unhealthy houses could give negative effect to its inhabitants by physical structure, indoor environment and even the material construction. Formaldehyde emissions from fiber-board material; the release of asbestos from textured ceilings; and 
fibers from glass insulation material, are some potential effect of material construction that can dangerous for human health [10]. Unappropriated behavior of inhabitants was the main causes of unhealthy houses. The habit to not open the windows every day could disturb the air circulation, especially houses that are not provided with well ventilation [11]. Low eeconomic level of inhabitant also give a significant impact to the public health [12].

House has some functions such as a place to unwind, rest after the fatigue of everyday activities, to gather with the family, to protect themselves from danger, to give a symbol of social status, and to store wealth. It is also a physical structure that can be a shelter where is useful for physic, mental and social health situation both for the health of families and individuals [13]. Healthy houses are residential buildings that meet to the health requirements such as has a healthy bathroom, better clean water, waste and wastewater facilities, good air circulation, suitable residential density and floor design [14] 


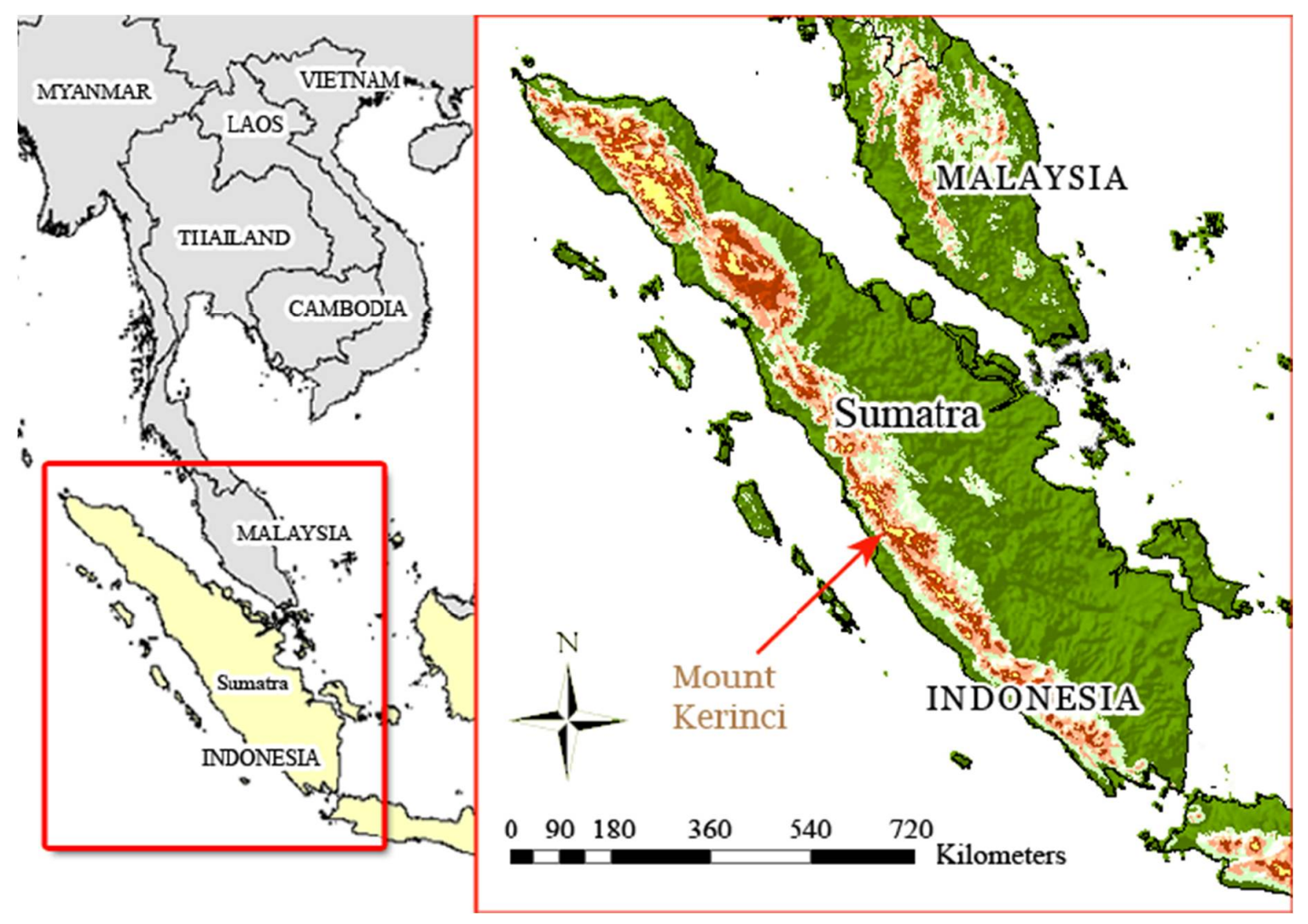

Figure 1. Administration Map of Kerinci District

The aim of the research was to get the information of negative effect of population growth impact especially unhealthy house and bad habits of residence on Kerinci district, Indonesia. Kerinci District has chosen as study area because it is classified as urbanization areas. It is also recorded to have 12.675 sufferer of upper respiratory tract infection [15] and continue to increase up to 16.801 sufferer in 2016 [16]. We also conducted strategical analysis to minimize unhealthy houses on Kerinci District. We use quantitative methods to quantify the number of healthy houses. This paper will give significant impact to increase healthy houses on Kerinci District. 


\section{Methodology}

This research has used qualitative method with questionnaires has spread to a hundred and six homes about characteristics of healthy home. The questionnaires have spread to Pondok village and Bukit Kerman village, Kerinci District, Jambi Province, Indonesia (Fig. 1). Random sampling has used to got home samples to get representative data about healthy houses [17] on Kerinci district. Qualitative method with descriptive analysis.

Research design of this research has used complete randomized design with four repetitions on every single question to minimize errors [18]. Questions on the questionnaire were based on questions from the health department of the Republic of Indonesia health center covers ceilings, walls, floors, bedroom windows, living room windows, ventilation, kitchen smoke holes, lighting, clean water facilities, latrines, waste water disposal facilities, garbage disposal facilities and occupant behavior with various criteria. Data analysis will be described with analysis descriptive to characterization of healthy houses [19].

Parameters used to determine healthy houses are as stated from Minister of Health No.829/Menkes/SK/VII/1999 concerning the health requirements of healthy housing. There are three components of assessment healthy houses: 1) the components of the house, including the ceiling, walls, floors, ventilation, smoke removal means kitchen and lighting. 2) Sanitation, including clean water supply, sewerage, waste water disposal, means landfills. 3) The behavior of the occupants, opening window of the room at home, cleaning up the house and yard, throwing feces into the pit, throwing garbage in the trash [20]. Variables characteristics of healthy houses has given value from zero until two based on the level of presence or absence criteria of every single variable and treatment on house 
component and occupant behavior while sanitation facilities has given value from zero till four and then total value multiplied by weight, healthy houses must get score between 1068 until 1200 and unhealthy house get score less than 1068 (Table 1).

Table 1. Questionnaire of Healthy Houses

\begin{tabular}{lll}
\hline No & \multicolumn{1}{c}{ Variable } & \multicolumn{1}{c}{ Operational Variable } \\
\hline 1 & Houses Components & Living room, dining room, bedroom, kitchen, floor, roof, wall, \\
& windows, smoke exhaust, pipe, lamp \\
& Behavior of & a. intensity of opening window bedroom \\
& Population & b. intensity of cleaning family's room \\
& c. intensity of cleaning house and yard \\
& d. the habit of throwing baby and toddler feces into the toilet \\
& e. the habit of throwing crash in the spam \\
& a. Clean water facilities \\
& b. Disposal facilities \\
& c. Wastewater disposal facilities \\
& d. Trash facilities
\end{tabular}

Analysis of healthy house has used much variables by Indonesian health department as much occupancy density (OD) (equation 1) and analysis of high indoor environment is following equation 2 :

$$
O D=\frac{O}{S H}
$$

O: occupant

SH: spacious house 


$$
\mathrm{P}(\%)=2 \mathrm{x}\left(\text { Temperature, }{ }^{\circ} \mathrm{C}-50\right)
$$

\section{Result and Discussions}

Healthy houses is an important issue for human health because a good people are healthy people, some reason for make a people healthy is house. The association between substandard housing and health has long been recognized [21]. Kerinci district have some problem about healthy houses. Any variables have used to analyze about quality standard of healthy houses on Kerinci. However, only recently has a growing body of evidence emerged suggesting that physical and mental health problems-anxiety, depression, attention deficit disorder, substance abuse, aggressive behavior, asthma, heart disease, and obesity — relate to the built environment, particularly to poor urban planning and inadequate housing [6]. Healthy houses' indicator has used to identify a hundred and six houses on Kerinci by Healthy Department Indonesian Standard covers floor condition, windows, ventilation, palate, kitchen smoke hole, lightning intensity, sanitation facilities like clean water, toilet, trash and any occupant behavior.

\section{Respondent}

This research has chosen 106 respondent has chosen with random sampling method, Respondent has classified by work; no work (0), farmer (1), trader (2), business man (3), state civil apparatus (4), private sector worker (5) and housewife (6) (Fig 2) and education levels. 


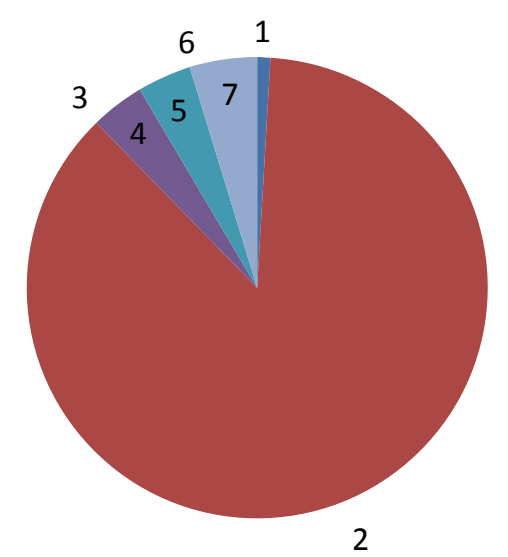

$\square 1 \square 2 \square 3 \square 4 \square 5 \square 6 \square 7$

Figure 2.Job Classification and Total Worker

Kerinci Mountain that is the reason majority of residence on Kerinci is famers. Highlands is a potential area to farm [22] like fruits and vegetables [23]. Respondent were chosen from Pondok and Pinggir Lingkat village, they was chosen as a respondent because on this village have many problems on healthy, far from city, have less medical person than others place and have less knowledge about healthy houses.

Type of worker respondent on Kerinci district has dominated by farmer as much 92 peoples, housewife is five peoples, state civil apparatus and private sector worker is four peoples, one people no work and nothing as a business man. Low education levels has a reason why unhealthy houses on Kerinci highest. Classification of education levels could see on figure 3. Education levels has classified from no educated (0), elementary school (1), junior high school (2), senior high school (3) and graduated (4) (Fig 3). 


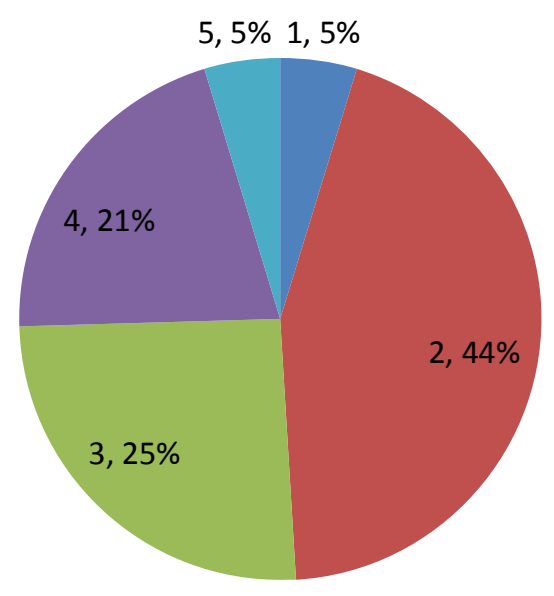

Figure 3.Education Levels

Education levels of Kerinci residence dominated by low education levels especially elementary school as much 47 peoples, junior high school 27 peoples, senior high school 22 peoples, graduated and no education levels is five peoples.

\section{Occupant Density Analysis}

As an analysis result has obtained eleven out of one hundred and six houses classified as very dense, it is same like only $10 \%$ houses of Kerinci too dense and $90 \%$ is no dense (Fig 4). The average space index was $25.7 \mathrm{~m} 2 /$ person, with a range from 7.0 to $55.7 \mathrm{~m} 2 /$ person [24], the net floor area available to houses was compared with the number of people working in the same premises in modern office buildings located in the centers of large cities. The net floor area included actual workstations and other related space in the tenant's use. The comparison showed that in most major Western cities, there was an average of $20 \mathrm{~m}^{2}$ of room space per person, while in China, Japan and the UK the number was just over $10 \mathrm{~m}^{2}$. This raises the question as to whether houses in other countries should improve the efficiency of the space they use. After all, it is obvious that costs per person fall with an 
increase of the number of persons working in a given space of a given area. Effective use of space may, however, also have negative consequences [7].

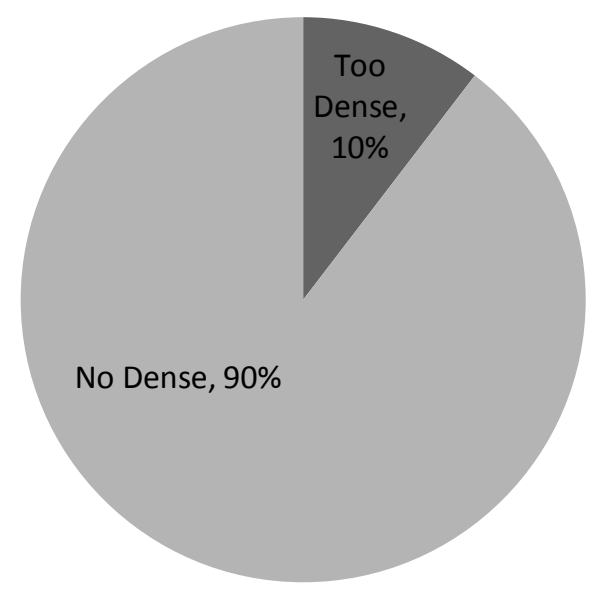

Figure 4.Ocupancy Density Level

Occupancy density level could describe about level of density as a variable of healthy houses. High occupant will give an impact to temperature, several study has given an information about indoor climate caused by high density occupant level could reduce performance and productivity [25]. Recent review summaries the results from field and laboratory studies on links between room temperature and performance [26]. The paper has present model on the average effect of temperature on performance, it has concluded that productivity decreases by $2 \%$ per each degree over $25^{\circ} \mathrm{C}$ and presented the link between a decrement in productivity $\mathrm{P}(\%)$ and high indoor temperature (equation 2 )

The comparative calculations for the refurbishment alternatives took the loss of productivity by high indoor temperatures into account, it has caused by high density occupants. The decrement of performance caused by high indoor temperatures was 
estimated by working hours per person using the simulations designed for the IDA-ICE program and theeq 2 . In the simulations, the decrement of performance was calculated based on an operative temperature.

The guidance provides the best evidence for six priority topics - crowding, low indoor temperatures, insulation, high indoor temperatures, injury hazards, and housing accessibility. High occupancy density level also happen on poor housing poor housing on health is a matter of international concern, high occupancy density level has caused by population growth, as the world population is growing and ageing and the effects of climate change are felt, designing cross-sectoral interventions addressing poor housing will be crucial if we are to achieve the Sustainable Development Goals on health (SDG 3) and sustainable cities (SDG 11). Going forward, health must remain a central consideration to meet future global housing needs [27].

Table 2.Design Values Of Defined Indoor Climate Levels

\begin{tabular}{|c|c|c|c|c|c|c|c|}
\hline \multirow[t]{2}{*}{$\begin{array}{c}\text { Indoor Climate } \\
\text { Level/Room type }\end{array}$} & \multicolumn{2}{|c|}{$\begin{array}{c}\text { Indoor } \\
\text { Temperature }\end{array}$} & \multicolumn{2}{|c|}{$\begin{array}{l}\text { Outdoor air } \\
\text { supply rate }\end{array}$} & \multicolumn{2}{|c|}{ Air Velocity } & \multirow{2}{*}{$\begin{array}{c}\text { Filter class } \\
\text { of supply } \\
\text { air }\end{array}$} \\
\hline & Winter & Summer & $\mathrm{L} / \mathrm{sm}^{2}$ & $\begin{array}{c}\mathrm{L} / \mathrm{s} \\
\text { person }\end{array}$ & $\begin{array}{l}\text { Winter } \\
(\mathrm{m} / \mathrm{s})\end{array}$ & $\begin{array}{l}\text { Summer } \\
(\mathrm{m} / \mathrm{s})\end{array}$ & \\
\hline \multicolumn{8}{|l|}{$\begin{array}{c}\text { Indoor Climate } \\
\text { Level S1+ }\end{array}$} \\
\hline Home Space & 21 & 24 & $>3$ & $>25$ & $<0,14$ & 0,15 & EU 8 \\
\hline Family Space & 21 & 24 & $>4$ & $>12$ & $<0,14$ & 0,15 & EU 8 \\
\hline \multicolumn{8}{|l|}{$\begin{array}{c}\text { Indoor Climate } \\
\text { Level S2+ }\end{array}$} \\
\hline Home Space & 21 & 25 & $>2$ & $>12$ & $<0,17$ & 0,2 & EU 7 \\
\hline Family Space & 21 & 25 & $>4$ & $>12$ & $<0,17$ & 0,2 & EU 7 \\
\hline \multicolumn{8}{|l|}{$\begin{array}{l}\text { Indoor Climate } \\
\text { Level S2+ }\end{array}$} \\
\hline Home Space & 21 & 27 & $>2$ & $>12$ & $<0,17$ & 0,2 & EU 7 \\
\hline Family Space & 21 & 27 & $>4$ & $>12$ & $<0,17$ & 0,2 & EU 7 \\
\hline
\end{tabular}


The ventilation of meeting rooms is controlled on demand [28] [29] [30]. Information code of S1, S2 and S3

\section{S1: Individual Indoor Environment}

The indoor air quality of the space is very good and there are no detectable odors in the environment. There is no damage decreasing the quality of indoor air in the spaces or structures connected to indoor air, and there are no sources of impurities. Thermal environment is comfortable, and there is no draught or overheating. The user of the space may individually control the thermal conditions. The space has a very good acoustic environment in view of its use and individually adjustable lighting supporting.

\section{S2: Good indoor environment}

The indoor air quality of the space is good, and there are no disturbing smells in the environment. There is no damage de- creasing the quality of indoor air in the spaces or structures connected to indoor air, and there are no sources of impurities. Thermal environment is good. There is usually no draught, but overheating is possible on summer days. The space has a good acoustic and lighting environment in view of its use.

\section{S3: Satisfactory indoor environment}

The indoor air quality and the thermal environment of the space meet the minimum requirements set by the building codes. The target and design values for individual factors can be selected from different categories, or, if necessary, the value of a factor can be specified separately [30].

This research describe only $10 \%$ has too dense occupants level and research location on highland made the density level on this area is not a problem but $10 \%$ houses. The $10 \%$ 
houses has too dense caused by poor, poor has made person could not make a healthy houses. Poor is an international problem especially on developing country [31]. Indonesia has rich forest but peoples stay poor [32] especially on Kerinci district who's on highland place.

\section{Air Quality of Kerinci}

The occupants of all buildings have a right to healthy indoor air. However the air in buildings can contain a range of pollutants that adversely affect the cardiovascular, endocrine, immune, nervous, and respiratory systems of the human body. Exposure lowers physical and mental health, well-being, and productivity with social, political, and economic consequences. Research location is on highland areas with less motorcycle activities, air quality on Kerinci is well, it has checked by Department of Local Environmental [33] Temperature on research location usually less than $20^{\circ} \mathrm{C}$ on morning and between $20-30^{\circ} \mathrm{C}$ on midday, it caused by location is on mountain area.

As we can see on figure six until figure 8 the climate here is tropical. Kerinci Kiri has a significant amount of rainfall during the year. This is true even for the driest month. The climate here is classified as Aft by the Köppen-Geiger system. The average annual temperature in Kerinci Kiri is $27.0{ }^{\circ} \mathrm{C}$. Precipitation here averages $2533 \mathrm{~mm}$. here is a difference of $178 \mathrm{~mm}$ of precipitation between the driest and wettest months. During the year, the average temperatures vary by $1.3{ }^{\circ} \mathrm{C}$. Air quality on kerinci could see on figure 9 .

Table 3.Air Quality on Kerinci District

\begin{tabular}{ccccc}
\hline Area & Place & $\mathrm{SO}_{2}\left(\mu \mathrm{g} / \mathrm{m}^{3}\right)$ & $\mathrm{NO}_{2}\left(\mu \mathrm{g} / \mathrm{m}^{3}\right)$ & $\mathrm{O}_{3}\left(\mu \mathrm{g} / \mathrm{m}^{3}\right)$ \\
\hline Office & $\begin{array}{c}\text { Koramil Kerinci } \\
\text { Mountain }\end{array}$ & 1,43 & 21,12 & 14,75 \\
Transportation & $\begin{array}{c}\text { Sulak Gedang } \\
\text { Sulan }\end{array}$ & 22,22 & 49,51 & 13,36
\end{tabular}




\begin{tabular}{ccccc} 
Settlement & $\begin{array}{c}\text { Village } \\
\text { Kemantan's } \\
\text { High }\end{array}$ & 0,865 & 11,52 & 12,69 \\
& $\begin{array}{c}\text { Industry } \\
\text { Tea Industrial }\end{array}$ & 3,77 & 20,72 & 23,87 \\
\hline Average & & 2,072 & 25,72 & 16,16 \\
\hline Quality standard & & 365 & 150 & 50 \\
Source: [33] & & &
\end{tabular}

Kerinci has been cooling temperature on outdoor and indoor environment than other place on Jambi Province caused on highland area and near from mountain, but the problem is every single time Kerinci has populated growth. It is will be give an impact to improved use of space and an improvement in the quality of indoor climate on space costs. Various degrees of improvement in indoor climate were designed for the given house plan. Refurbishment, operation and maintenance costs for them were estimated (Table 3).

On the others areas (not highland areas) recruitment has that in minimum level 1 refurbishment would generally retain the interior surface and the levels 2 and 3 all of the interior walls would have to be replaces and surface repainted. The cost of modernizing open-plan offices included the cost of the moveable partitions placed between the workstations (EUR 590/workstation, incl. VAT 22\%). The differences in the operation and maintenance costs are based mainly on range in the costs of cleaning and energy.

Alternative refurbish on 1-A and 1-B (Table 2) current indoor climate quality has improves with mechanical cooling of air supply to lower high temperatures. Additional alternative 1-B included a cooling system with local cooling devices (fan coils and chilled beams) and room control of temperature. In alternatives 2-0 and 3-0 the quality of indoor conditions attainable with the existing ventilation system were not altered. Kerinci have 
good air condition, less temperature than else, less air pollution than else, it caused why Kerinci did not need cooling machine and it will be minimize cost to make healthy houses.

Table 4. Space indexes of the refurbishment alternatives, degree of refurbishment (percentage of new building), annuities of refurbishment costs (20 years, $4 \%$ ), and maintenance costs (VAT 22\%). Case building.

\begin{tabular}{|c|c|c|c|c|}
\hline Renovation Alternative & & $\begin{array}{c}\text { Occupant } \\
\text { Density } \\
\left(\mathrm{m}^{2} / \text { person }\right)\end{array}$ & $\begin{array}{l}\text { Renovation } \\
\text { Degree \% }\end{array}$ & $\begin{array}{l}\text { Operation, } \\
\text { Maintenance } \\
\text { and energy } \\
\text { Cost }(€ / v r)\end{array}$ \\
\hline Current lay-out & & 19.59 & & \\
\hline $1-0$ & $\begin{array}{l}\text { No } \\
\text { renovation }\end{array}$ & & 0 & 42,000 \\
\hline $1-\mathrm{A}$ & $\begin{array}{l}\text { Cooling of } \\
\text { air supply }\end{array}$ & & 8 & 42,000 \\
\hline $1-\mathrm{B}$ & $\begin{array}{c}\text { Cooling } \\
\text { system with } \\
\text { local control }\end{array}$ & & 11 & 43,000 \\
\hline Conversion to cell room & & 18.50 & & \\
\hline $2-0$ & $\begin{array}{l}\text { No indoor } \\
\text { climate } \\
\text { renovation }\end{array}$ & & 53 & 45,000 \\
\hline $2-\mathrm{A}$ & $\begin{array}{c}\text { Indoor } \\
\text { climate level } \\
\text { S3+ }\end{array}$ & & 57 & 45,000 \\
\hline $2-\mathrm{B}$ & $\begin{array}{c}\text { Indoor } \\
\text { climate level } \\
\text { S2+ }\end{array}$ & & 56 & 47,000 \\
\hline $2-\mathrm{C}$ & $\begin{array}{c}\text { Indoor } \\
\text { climate level } \\
\text { S1+ }\end{array}$ & & 57 & 47,000 \\
\hline $\begin{array}{c}\text { Conversion to open-plan } \\
\text { office }\end{array}$ & & 7.57 & & \\
\hline $3-0$ & $\begin{array}{l}\text { No indoor } \\
\text { climate } \\
\text { renovation }\end{array}$ & & 50 & 40,000 \\
\hline $3-\mathrm{A}$ & $\begin{array}{c}\text { Indoor } \\
\text { climate level } \\
\text { S3+ }\end{array}$ & & 55 & 40,000 \\
\hline $3-\mathrm{B}$ & $\begin{array}{c}\text { Indoor } \\
\text { climate level } \\
\text { S2+ }\end{array}$ & & 54 & 41,000 \\
\hline $3-\mathrm{C}$ & Indoor & & 55 & 41,000 \\
\hline
\end{tabular}


climate level

$\mathrm{S} 1+$

Temperature of Kerinci has been between $20-30^{\circ} \mathrm{C}$, it is corresponding with thermal value of environment has classified around $20^{\circ} \mathrm{C}$ of S1 to S3 (Table 4) and the target values for operative temperature (Fig 8). Outdoor temperature to refers to the floating 24-hour average for outdoor air at the close sweat her observation site. Outdoor temperature tumid refers to the average of the outdoor temperature over a maximum period of five hours. At the request of the user of the space, the temperature may be allowed to fall below the target or rise above it in the summer. The temperature must remain within the allow able deviation range from the target value for the time required by the stability of the environment calculated from the planned time of use of the building. The floating one hour average temperature must not fall below the minimum or exceed the maximum values with the planned use at design temperatures. The carbon dioxide concentration target applies to carbon dioxide from humans and is measured with an infrared meter, for instance. The ambient concentration is included in the target value. The radon concentration in the room air for new residences as specified by the Ministry of Social Affairs and Health shall not exceed $200 \mathrm{~Bq} / \mathrm{m} 3$. The annual average concentration of radon $\mathrm{n}$ residences shall not exceed $400 \mathrm{~Bq} / \mathrm{m} 3$. The stability of the environment is measured through application of the floating one-hour average for carbon dioxide concentration [30]. 

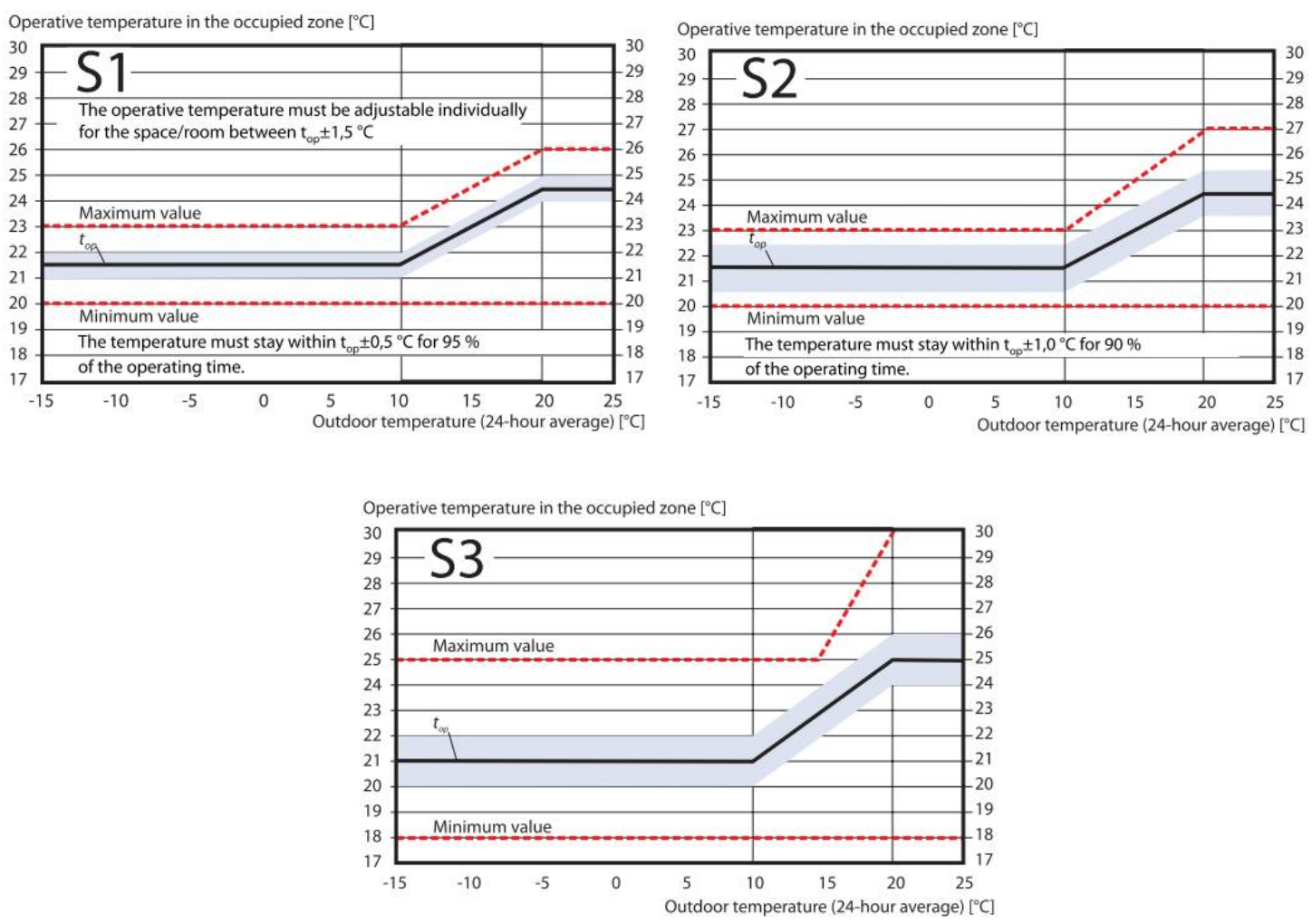

Figure 5. Target values for operative temperature [30]

Air quality on indoor environment has hard relationship with ventilation and total person on room (Fig 9). Some disease can be caused by air supply per occupant [34], it could get worse if indoor air environment has contaminated with mold, pet fur and tobacco smoke [35]. The stand or fall of indoor environment directly affect the life quality of humans, if on a house room have much people it could give an impact to carbon dioxide and make highest temperature. That does will be give an impact for concentration and health of occupant.

\section{Healthy Houses Analysis}

Healthy houses has analyzed by occupant behaviors and houses component (see healthy houses component has published by Indonesian Department of Health). Healthy 
houses component has analyzed with software to make analysis easily, from 106 houses sample, only eight houses is healthy souses and 98 houses is unhealthy, it's same like only 7,55\% healthy houses and 92,45\% unhealthy houses (Fig 9) on Kerinci District especially Pondok and Pinggir Lingkat village.

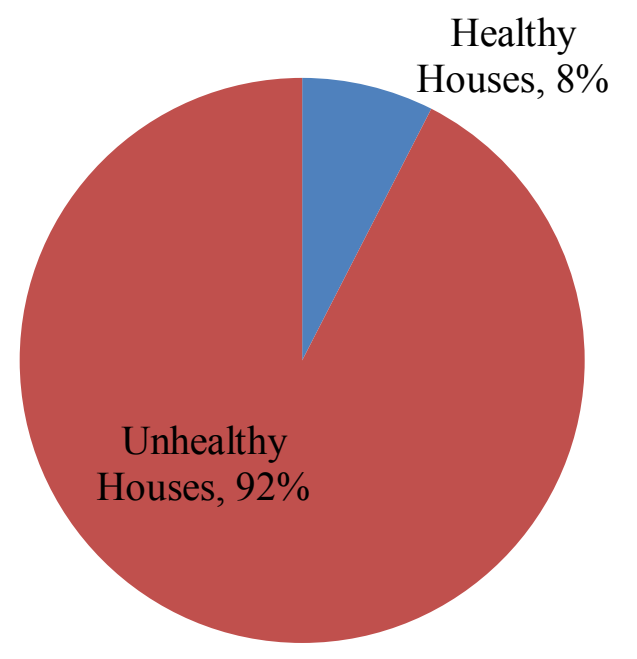

Figure 6. Percentage of healthy houses on Kerinci

Unhealthy houses has caused by awareness of the importance of maintaining home health, it caused by low education levels on Kerinci District (Fig. 3). Several research also made a relationship about unhealthy with low income family, on some place it give an impact to conflict [36], education levels could give an impact to lifestyle and health and healthy lifestyle give an impact to health (Fig 10) especially education, skills, resources and abilities that enable to achieve a better life [37].

Concept of human capital suggests the effective individuals gain control of their health by developing a healthy lifestyle. The result supports the view of education as learned effectiveness. This research indicates that economic headship accounts for most of the 
negative effect of low household income on health. In generally prosperous circumstance, lifestyle becomes a dominant factor in health because most people have educated income. The Impact of Education on Health Outcomes and Behaviors in a Middle-Income always a problems especially on developing country [38].

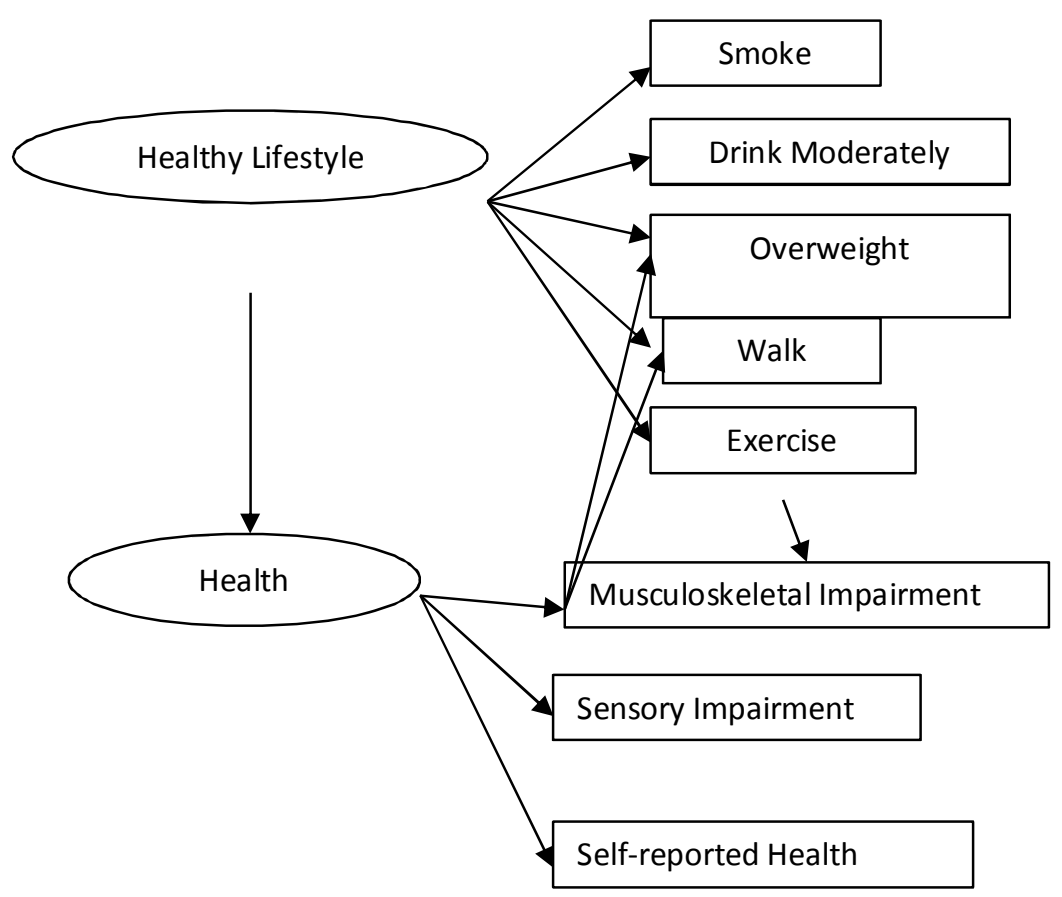

Figure 7. Healthy Lifestyle and Health

House's ceiling is a parameter of healthy houses, in this research has classified about ceiling houses from no ceiling, there are, dirty, difficult to clean and prone to accidents and available, clean and no prone to accidents with score zero for nothing ceiling, one for dirty and two for clean. The result describe presentation of ceiling on this location $50 \%$ houses on Kerinci is have not ceiling, $12 \%$ have dirty, difficult to clean and prone to accidents and only $38 \%$ have clean ceiling and no prone to accidents. This research explains half of respondent didn't have a parameter of healthy houses. 
In planning the construction details that will be used in a house, it is very important to consider moisture control. Too much moisture in a house, or moisture that gets trapped in wall or ceiling cavities, can cause significant problems, ranging from structural deterioration to degraded insulation performance, to some of our most serious indoor air quality problems, such as mold. As with heating, cooling requirements can be dramatically reduced through careful building design. In addition to high levels of insulation and tight construction, consider measures to reflect or block sunlight [39].On research location, houses has made by not a wall (made of woven or weeds), semi permanent wall (made of and wall, $36 \%$ houses on this location made by wall, $37 \%$ by semi permanent and no wall is $27 \%$. Floor houses has made of soil is 10 houses, woven board is 18 houses and plaster, tiles, ceramics/boards is 78 houses, 93 houses have

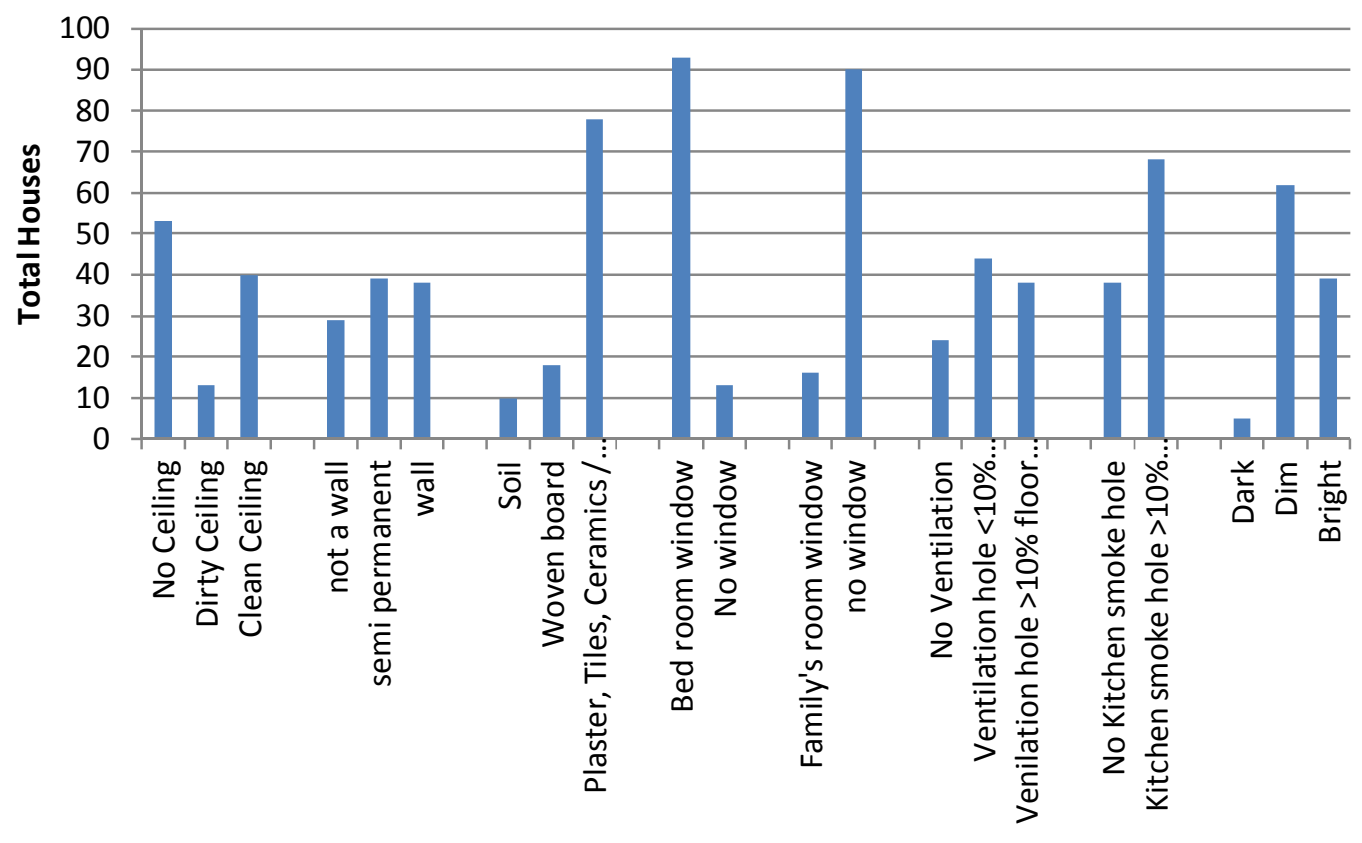

Figure 8. Houses Component 
bedroom window and only 13 houses not have bedroom widow, 16 houses having windows in family's room and 90 houses did not have window, 24 houses not have ventilation, 44 houses have ventilation less than $10 \%$ floor area and 38 houses have ventilation more than $10 \%$ floor area, 38 houses do not have kitchen smoke holes and 68 houses have kitchen smoke holes and the last component is lightning, 5 houses have not bright, can't be used to read, 62 houses less bright, so it's not clear to read normally and 39 houses bright and not glare so that it can be used to read.

It has not qualified by International Healthy Houses Standard, every foundation, roof, floor, exterior and interior wall, ceiling, inside and outside stair, porch, trim, accessory structure, fence, door, window, and window glass shall be safe to use and capable of supporting the intended design loads and load effects and shall be in good condition, Every plumbing fixture and pipe, chimney, flue, smoke pipe, and every other facility, piece of equipment, or utility shall be installed in conformance with applicable statutes, ordinances, and regulations, Mechanical, utility, and heating equipment shall be separated from habitable rooms. In multifamily buildings, equipment rooms shall be locked. Every plumbing fixture, stack, vent, water, waste, and sewer pipe shall be properly installed, maintained in a safe and functional order, and kept free from obstructions, leaks, and defects, an approved potable water supply system shall provide an adequate amount of running water under pressure to all fixtures simultaneously. An adequate supply of heated running water under pressure shall be supplied to sinks, bathtubs, showers, and laundry facilities. Water heaters shall be set at a minimum temperature of $110^{\circ} \mathrm{F}\left(43^{\circ} \mathrm{C}\right)$. At bathtub faucets and shower heads, the maximum temperature shall be $120^{\circ} \mathrm{F}\left(49^{\circ} \mathrm{C}\right)$. Heated water shall be provided by either a tank-type or thankless water heater. A tank-type 
water heater shall have a temperature/pressure relief valve that discharges to a drip pan, storage tank, or the outside. The temperature of water discharged from a thankless water heater shall not exceed $140^{\circ} \mathrm{F}\left(60^{\circ} \mathrm{C}\right)$; every waste pipe shall be connected to a public sewer system, an approved private sewage disposal system, or the dwelling's gray water system. No toilet waste pipe shall be connected to a gray water system. The drainage system shall have a cleanout. Faucet discharge points shall be located above the overflow rim of sinks, tubs, or other fixtures that collect water. A kitchen sinks in good working condition that is properly connected to heated and unheated water supplies and waste pipes. Any provided dishwasher and components of the sink, including disposal and water filtration devices, shall be in good working condition and properly connected. A counter for food preparation and cabinets and/or shelves sufficient to store occupants' food that does not require refrigeration and eating, drinking, and food preparation equipment. Cabinets shall have tight-fitting doors and no gaps between any surfaces. The counter, countertop edges, cabinets, and shelves shall be of sound construction and furnished with surfaces that are impervious to water, smooth, and cleanable. A range for cooking food. The range shall be properly installed with all necessary connections for safe and efficient operation and shall be maintained in good working condition. The range shall include an oven unless both a separate oven, other than a microwave oven, and a cooktop are provided. A hot plate is not an acceptable substitute for burners on a range or cooktop. The range or cooktop shall have a vertical clearance of not less than 30 inches $(762 \mathrm{~mm})$ from above its surface to unprotected combustible material. Reduced clearances are permitted in accordance with the listing and labeling of the range hood, Ventilation for the range shall be provided in accordance with Subsection 5.3. A refrigerator with a freezer. The refrigerator shall be in 
good working condition, of sufficient size to store occupants' food that requires refrigeration, and capable of maintaining a temperature less than $41^{\circ} \mathrm{F}\left(6^{\circ} \mathrm{C}\right)$ but more than $32^{\circ} \mathrm{F}\left(0^{\circ} \mathrm{C}\right)$. The freezer section shall be capable of maintaining a temperature below $0^{\circ} \mathrm{F}$ $\left(-18^{\circ} \mathrm{C}\right)$, If the lease does not provide for a refrigerator, adequate connections for the occupant's installation and operation of a refrigerator shall be provided, A kitchen floor in good condition with a sealed, water-resistant, nonabsorbent, and cleanable surface.

Floors and floor coverings shall be attached at each threshold, maintained in safe and healthy condition, capable of being cleaned, and free of bulges and buckling. Carpets shall have no tears, folds, or bumps. The structure and facilities shall be maintained so that the noise level in the interior of the dwelling unit caused by exterior sources is below $45 \mathrm{~dB}$ Ldn (day-night equivalent sound level). On electrical system Every dwelling unit shall have electric service, outlets, and fixtures that are grounded and installed properly, maintained in good and safe working condition, and connected to a source of electric power, Every dwelling unit shall be supplied with a three-wire, 120/240-volt, single-phase electrical service that is not shared with another dwelling unit. Temporary wiring or extension cords shall not be used as permanent wiring, every habitable room shall receive daylight from at least one exterior window or skylight, if a habitable room receives daylight from an adjacent room or area used seasonally, such as a porch, the daylight through this interconnection shall be available year-round. Every bathroom and kitchen shall comply with the daylight requirement for habitable rooms contained in this section, unless the room is equipped with a ventilation system consistent with Subsection 5.3, each room containing a toilet, sink, bathtub, or shower stall shall contain at least one ceiling- or wall-type electric lighting fixture. Each non-habitable room, including laundry rooms, furnace rooms, and 
public halls, shall contain at least one ceiling or wall type electric lighting fixture, Light switches that control ceiling- or wall-type electric light fixtures shall be located conveniently for safe use, Every public hall, exterior entry door, and stairway in multifamily housing shall be illuminated at all times by ceiling- or wall-type electric lighting fixtures providing 800 lumens for every $200 \mathrm{ft} 2(18.6 \mathrm{~m} 2)$ of floor area. The distance between light fixtures shall not be greater than 30 feet $(762 \mathrm{~cm})$. National, In a building containing one or two dwelling units, every public hall, exterior entry door, and stairway shall be illuminated by ceiling- or wall-type electric lighting fixtures providing 800 lumens for every $200 \mathrm{ft} 2(18.6 \mathrm{~m} 2)$ of floor area that is controlled by a three-way switch or a motion-activated device. Facilities for heating, cooling, ventilation, and humidity control shall be maintained in good working condition and operated when necessary for the health and comfort of the occupants and in accordance with the design capacity of the installed equipment. Within 48 hours after equipment has become inoperative due to a mechanical problem or power failure other than a utility outage, an alternative safe source of necessary heating, ventilating, or cooling shall be provided. Furnaces, water heaters, wood stoves, and other devices that employ combustion-burning fuel shall be vented to the outside of the structure in an approved manner that meets manufacturer specifications and is in compliance with applicable codes and standards (e.g., ANSI 223.1/NFPA 54 National Fuel Gas Code, NFPA 31 Standard for the Installation of Oil-Burning Equipment, NFPA 211 Standard for Chimneys, Fireplaces, Vents, and Solid Fuel-Burning Appliances) and shall be supplied with sufficient air to support the continuous complete combustion of fuel and prevent back drafting. 
Natural or mechanical ventilation, or a combination of the two, shall deliver fresh air to every habitable room and bathroom and be capable of removing moisture-laden air and other contaminants generated during cooking, bathing, and showering. Every dwelling shall have a ventilation system compliant with ASHRAE Standard 62.2 (Ventilation and Acceptable Indoor Air Quality in Low-Rise Residential Buildings) or ASHRAE 62.1 (Ventilation for Acceptable Indoor Air Quality) as applicable to the dwelling, The air exhausted from a bathroom, toilet room, kitchen, clothes dryer, or basement shall not be vented into any other parts of the building's habitable space or an attic; such air shall discharge directly to the outdoors but not near any intake on the building exterior, The exhaust vent from a clothes dryer shall consist of a rigid or corrugated semi-rigid metal duct, Pipes, ducts, conductors, fans, and blowers shall not discharge gases, steam, vapor, hot air, grease, smoke, odors, or other gaseous or particulate wastes directly upon abutting or adjacent public or private property or that of another occupant. Vent pipe openings and any pest-proofing screens that cover them shall be maintained free of debris, Basement air shall not be used as supply air for an air handling system. Every foundation, roof, roofing component, exterior wall, door, skylight, and window shall be watertight, weather tight, free of persistent dampness or moisture, and in good condition. The building's drainage system, such as footing or foundation drains, gutters, downspouts, rainwater collection containers, or other elements, shall direct water away from the structure. Exterior wood surfaces shall be protected from the elements and decay by paint or other protective treatment. Weep holes in brickwork shall be left open. Premises shall be graded and maintained to prevent the erosion of soil and to prevent the accumulation of water on the premises, within a crawlspace, or within the structure. Interior and exterior surfaces and 
surface coverings, such as but not limited to carpet, wood, cellulose insulation, and paper, paint, and other wall coverings, including paper-faced gypsum board, shall have no signs of visible mold growth or chronic or persistent excessive dampness or moisture. Building material that is discolored or deteriorated by mold or mildew or causes a moldy or earthy odor shall be cleaned, dried, and repaired. Structurally unsound material shall be removed and replaced. Removal and repair of moldy material shall be conducted in accordance with New York City's Guidelines on Assessment and Remediation of Fungi in Indoor Environments, the Institute of Inspection, Cleaning, and Restoration Certification's IICRC S520 Standard and Reference Guide for Professional Mold Remediation or the EPA guidelines for Mold Remediation in Schools and Commercial Buildings [7].

According American Public Health [40] of duties of owners and occupant, they must the duty to ensure that the structure, dwelling, dwelling unit, common areas, and premises are maintained in a safe and healthy condition, in compliance with this Standard and other applicable requirements. The owner shall ensure the collection of trash and recyclables and provide and maintain trash containers, bulk storage containers, recycling containers, and areas where the containers are stored, The owner shall maintain the building and premises to keep pests from entering the building and dwelling units, inspect and monitor for pests, and eliminate pest infestation in accordance with integrated pest management method, The owner shall provide occupants with at least 48 hours written notice of the planned use of a chemical agent such as a pesticide or herbicide, the date and location of application, and a copy of the warning label. The owner shall not cause or allow any water, sewage, electrical, or gas service, facility, or equipment required for safe and healthy occupancy to be removed, shut off, or discontinued for any occupied dwelling, 
except for such temporary interruption as may be necessary while repairs or alterations are being performed, or during temporary emergencies requiring discontinuance of service. This provision does not apply where the occupant has contractual control over the service and shall not be interpreted as preventing a utility company from discontinuing service for reasons allowed by law [40]. But on fact in Kerinci, Indonesia behavior of occupant has does not do what is done to create a healthy home.

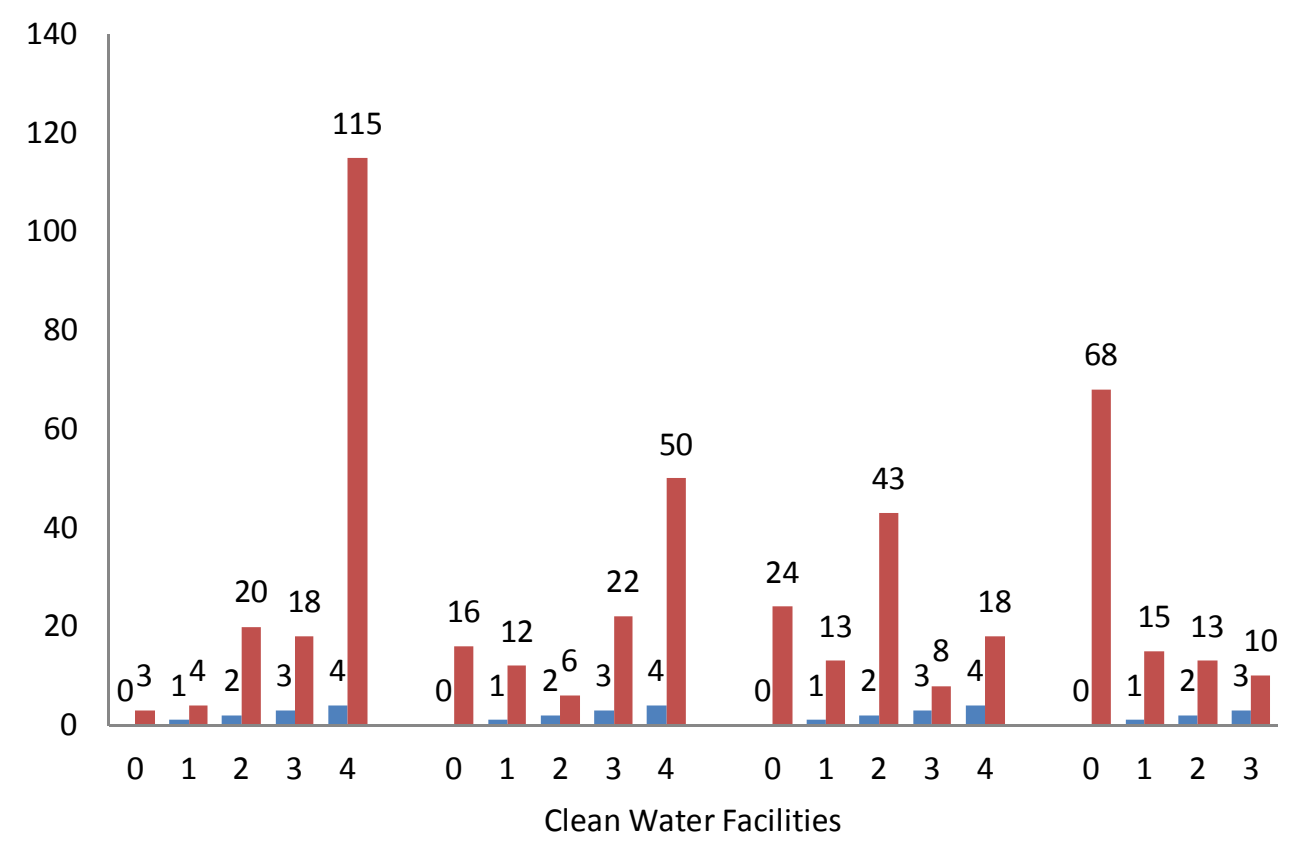

Figure 9.Sanitation Facilities 


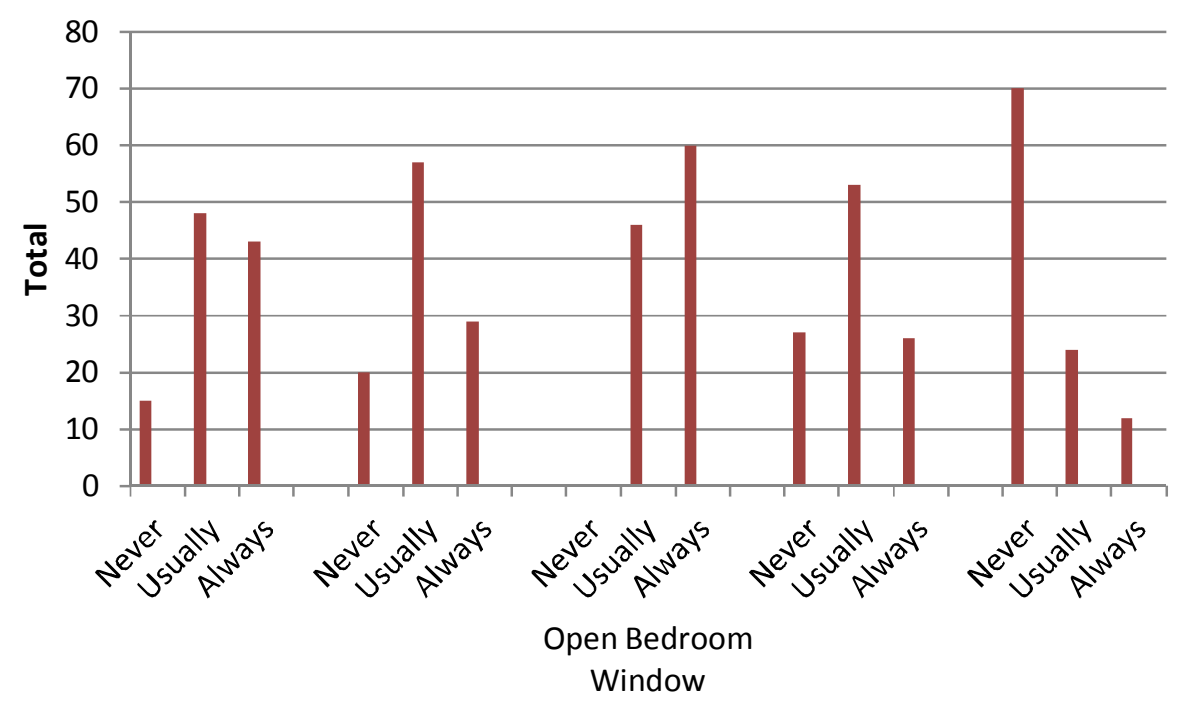

Figure 10. Occupant Behavior

Sanitation facilities has classified by availability and information. Information about number on figure 15 on clean water facilities is 0 for nothing clean water facilities, 1 for available, not private property and not qualified for health standard, 2 for available, private facilities and not qualified for health standard, 3 for available, private facilities and qualified for health standard and 4 for available, not private facilities and qualified for health standard. Dirt disposal facilities is 0 for nothing disposal facilities, 1 for available, not a goose neck, no lid, channeled into a river/pond, 2 for not a goose neck, have lid, channeled into a river / pond, 3 for not a goose's neck, there's a lid, a septic tank and 4 for available, goose neck, septic tank. Wastewater disposal facilities is 0 for nothing, so it is flooded irregularly on the yard, 1 for available, impregnated but contaminating water sources (distance with water source less than $10 \mathrm{~m}$ ), 2 for available, streamed to open sewers, 3 for available, impregnated and does not contaminate water sources (distance with water source is more than $10 \mathrm{~m}$ ) and 4 for available, streamed to closed sewers (city 
channels) for further processing. The last is solid waste facilities is 0 for nothing, 1 for available but not waterproof and no lid, 2 for available, waterproof but no lid and 4 is available, waterproof and have lid. As a research resident on Kerinci have clean water facilities well, it caused by they has living on highland area, near from course of fresh water on mountain but they not yet have dirt disposal facilities, solid waste disposal facilities and wastewater disposal facilities well. Occupant behavior has classified for behavior of occupant with parameters such as open the window of bedroom, open window on family's room, cleaning house, throw baby toddler feces into the toilet and throw spam with classification doing every day, usually and never on the right place. That is a some reason why unhealthy houses are majority on this location.

\section{Public Health Analysis}

To come up with a reasonable view on what the ultimate goals of public health are, we need to look at what more specific suggestions have been made. Among the different goals that have been suggested, there are at least three that are worth considering more closely, namely (1) to improve the average level of health (or the like) in the relevant population, (2) to reduce health inequalities between groups or individuals and (3) to create certain types of opportunities for health, most often equal opportunities. It is possible that we should add (4) to improve the health level of the worst-off groups [41]. Water is essential to sustain life, and a satisfactory (adequate, safe and accessible) supply must be available to all. Improving access to safe drinking-water can result in tangible benefits to health. Every effort should be made to achieve drinking-water that is as safe as practicable [42]. 


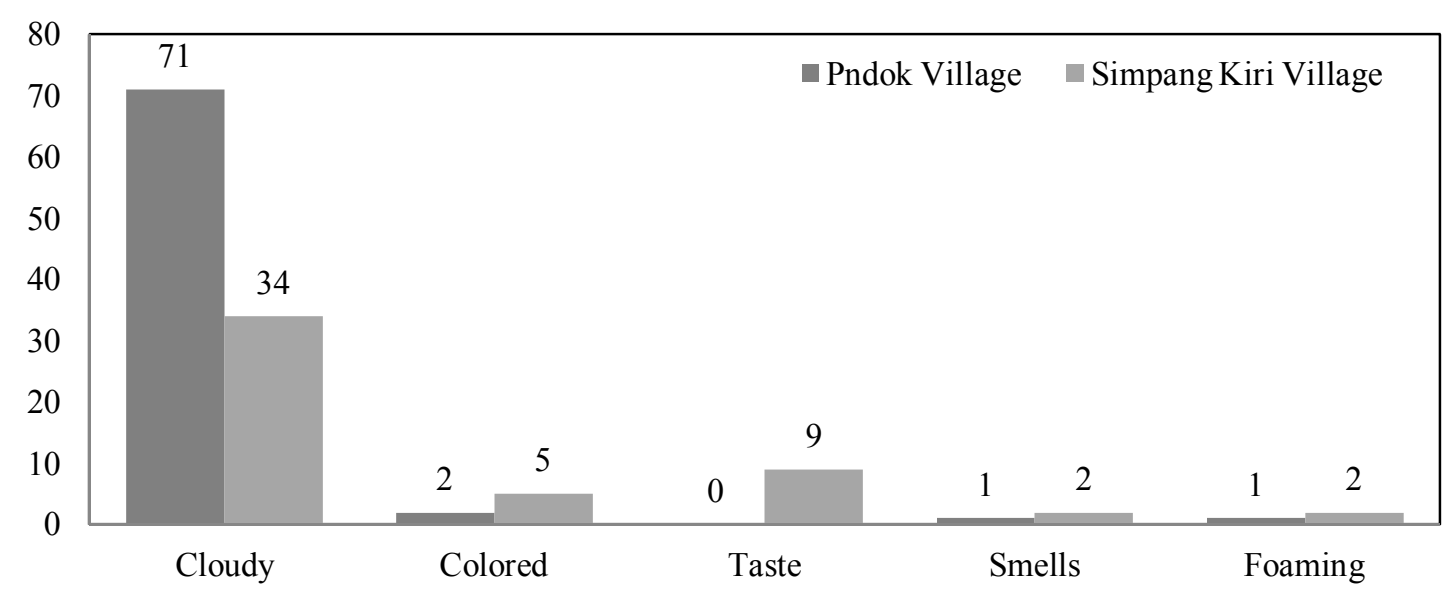

Figure 11. Physical Quality of Clean Water

Physical quality of clean water has classified by cloudy, colored, taste, smells and foaming, majority physical water quality has couldy on Pondok and Simpang Kiri Village. Several study has explain to solve cloudt waters [43], A new model for assessment of visual clarity impacts among clear water fisheries has emerged as a beta version, suitable for determining the impact status of a sediment pollution event in relation to the threshold of ill effects [44]. Many human activities threaten water quality. Some of these activities have been occurring for many generations and some began more recently. This section reviews these activities in relationship to the different water forms in the environment. Rivers and streams are the highways of the water world. People have used them to transport themselves and their goods from the mountaintops to the seas for centuries. Unfortunately, humans have used them also to dispose of and transport their wastes, a practice that seriously threatens water quality in our rivers and streams. Since ancient times, villages have been built on riverbanks. Wastes from these villages were thrown into the rivers to be carried away. At first, few people lived downstream and the rivers had the natural capacity to assimilate the waste and cleanse themselves. This natural capacity for a water body to 
cleanse itself is called assimilative capacity. As the population continued to grow, however, the assimilative capacities of the waters were overburdened and the rivers could no longer cleanse themselves. Today, most of us know it is unacceptable to discharge untreated waste into a river or stream. Waste dumped into a river upstream will be carried downstream to the users below. The phrase "we all live downstream" is often used to remind us to use our rivers wisely, respecting the rights of all downstream users. In turn, we hope the people living upstream from us will respect our rights. Although wastewater from most communities and industries is now routinely treated to remove pollutants, ultimately it is discharged into our rivers along with any pollutants that remain after treatment. Our efforts to keep rivers clean and healthy compete with this age-old practice of using our rivers to transport wastes. Sometimes wastes enter our rivers and streams through more spread out, indirect, or diffuse discharges, or nonpoint source discharges. For instance, fertilizers, pesticides, and herbicides can be carried from our lawns and fields into nearby waters during and after rainstorms, as a result of stormwater runoff and every wastes that affect to water quality [45]. Bad water quality that affected to skin disease [46] Cloudy is a parameter of wastewater, wastewater that affected public health on Kerinci such as diaarhea, disease of skin, other diseaseas, malaria and API caused another else. Diarrhoea results when there is loss of the dynamic and finely balanced absorption and secretion of water and electrolytes within the gut. Diarrhoea remains a major cause of morbidity and mortality worldwide and it is important for those who care for children to have a clear understanding of the pathophysiology of diarrhoea. Diarrhoea can be considered to be either osmotic or secretory. Osmotic diarrhoea occurs when excessive osmotically active particles are present in the lumen, resulting in more fluid passively moving into the bowel 
lumen down the osmotic gradient. Secretory diarrhoea occurs when the bowel mucosa secretes excessive amounts of fluid into the gut lumen, either due to activation of a pathway by a toxin, or due to inherent abnormalities in the enterocytes [47]. Acute Respiratory Infections (ARI) is a global health problem. Zinc stimulates immune responses and prevents infections. The present study reports the serum zinc level in children with acute respiratory infections, and also addresses the influences of sociodemographic factors, nutritional status and health care facility on the prevalence of acute respiratory infections [48]. The skin is the outermost organ of the body and is continuously exposed to external pathogens. Upon inflammation, various immune cells pass through, reside in or are recruited to the skin to orchestrate diverse cutaneous immune responses, if the pathogens has growing that affected to make skin diseases [49], external phatogens could come from wastewater, air polution and else.

\section{Percentage of Community Disease}

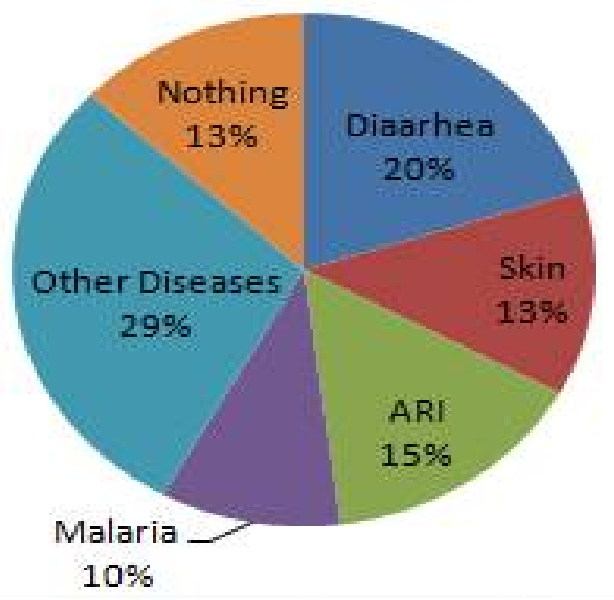

Figure 12. Percentage of Community Disease 
Standards for water quality should include factors that affect taste, solid buildup within water systems, and toxicity. Factors that should be observed for poultry production include, but are not limited to [50]:

Color: Water is colorless, and any color in the water may indicate an increased contamination level.

Turbidity: Particles such as clay, silt, sand or organic matter in suspension can cause the water to appear cloudy or muddy. Turbid water can cause leaky nipples and clog fogging nozzles. Hardness: Calcium and magnesium salts cause the water to be "hard" and can lead to scale and sludge buildup within water lines. Hardness reduces the effectiveness of soaps and disinfectants and interferes with the administration of some medications.

Iron (Fe): Iron will stain almost everything it contacts, and it is a common water quality issue. Recent studies indicate that iron in the water does not appear to affect poultry health, but some of the iron may form solid particulates such as iron oxide, which can lead to equipment problems. These small particles can cause leaky nipples and block fogging nozzle openings. Either of these conditions can have negative impacts on poultry production. Iron bacteria are more likely to thrive in water with high iron concentrations. As a result, biofilm buildup can occur, which can obstruct nipple drinkers and promote pathogen proliferation.

Manganese $(\mathrm{Mg})$ : While manganese itself does not cause a negative effect on poultry health, like iron, it can form solid particulates that can cause leaky nipples and clog foggers. Nitrate-N $(\mathrm{N})$ : Elevated nitrate concentrations indicate decaying organic material. It has been correlated with poor oxygen use in animals, but recent studies observed no differences 
in broiler performance with nitrate levels as high as $600 \mathrm{ppm}$. Presence of nitrate is a good indicator that water should be checked for bacteria.

$\mathrm{pH}$ : The $\mathrm{pH}$ is a measure of acidity or alkalinity. A scale from $0-14$ is used to measure $\mathrm{pH}$. A value of 7.0 is neutral, values below 7.0 are acidic and values greater than 7.0 are basic. A pH of 6.0 to 6.8 is preferred for broiler production, but birds can tolerate a $\mathrm{pH}$ range of 4 to 8 . A pH range of greater than 8 could cause reduced water consumption.

Alkalinity: Caused by calcium carbonate, bicarbonate or sulfate. High alkalinity increases the buffering capacity of water.

Total solids: Total solids represent the total amount of solid material in both suspension and solution. Total solids are not directly linked to any poultry health issues, but equipment function and water delivery could be negatively affected by total solids, which could influence bird performance.

Toxic compounds: The amount will vary depending on the compound, but elements such as lead, selenium and arsenic should be kept below $1.0 \mathrm{ppm}$ to prevent bird health problems as well as residues.

Dissolved oxygen: Normal ground water concentrations have little or no dissolved oxygen. Concentrations greater than zero indicate possible surface water influence.

Bacteria: Keep bacteria levels to a minimum.

\section{Conclusion}

Kerinci district has been analyzed and have 90\% unhealthy houses, it's will be problems for public health. Preventive and repressive needed to reducing unhealthy houses on Kerinci such as environmental strategy analysis to minimize unhealthy houses on Kerinci such as make a some regulation on local government to reducing unhealthy houses, 
The commitment of Bappeda and the Office of City Planning and Settlements provides maximum service, growing up quality of community, The function of the Office as a provider of accessibility as an effort to explore the lack of funds in the implementation of unhealthy housing programs, provide counseling and approaches to the community, village surgery to alleviate unhealthy homes, Increased revitalization of housing and settlement facilities and infrastructure to meet public access to adequate housing facilities and infrastructure services and explore the potential of regional ecotourism so as to increase public awareness to maintain cleanliness of homes and the environment, this will also improve the economy of the community and reducing unhealthy houses.

\section{Reference}

[1] Arku, G., Luginaah, I., Mkandawire, P., Baiden, P., \& Asiedu, A. B. (2011). Social Science \& Medicine Housing and health in three contrasting neighbourhoods in Accra , Ghana. Social Science \& Medicine, 72(11), 1864-1872. https://doi.org/10.1016/j.socscimed.2011.03.023

[2] United Narions Centre for Human Settlements. (1996). An Urbanizing World. Oxford University Press.

[3] Albalak, R. (1997). Cultural Practice and Exposure to Pariculate Pollution from Inddor Biomass Cooking: Effect on Repiratory Health and Nutritional Status Among Th Aymara Indians of The Bolivian Highland. Chemical reviews. University of Michigan. https://doi.org/10.16953/deusbed.74839

[4] Shaw, M. (2004). Housing and Public Health. Annual Review of Public Health, 25(1), 397-418. https://doi.org/10.1146/annurev.publhealth.25.101802.123036

[5] Dunn, J. R. (2000). Housing and health inequalities: Review and prospects for research. Housing Studies, 15(3), 341-366. https://doi.org/10.1080/02673030050009221 
[6] Kearns, A., Hiscock, R., Ellaway, A., \& Macintyre, S. (2000). "Beyond four walls". The psycho-social benefits of home: Evidence from West Central Scotland. Housing Studies, 15(3), 387-410. https://doi.org/10.1080/02673030050009249

[7] Shaw, M. (2004). Housing and Public Health. Annual Review of Public Health, 25(1), 397-418. https://doi.org/10.1146/annurev.publhealth.25.101802.123036

[8] Anggana Fitri S, Lily Tambunan, A. N. (2015). Public Health in Indonesia Residential Environment. In HABITechno International Seminar-Public Housing \& Technological Innovations For Sustainable Urbanization (pp. 1-10). https://doi.org/10.13140/RG.2.2.30929.94569

[9] Read, A. (2017). Integration of Daylighting into Educational ( School ) Building Design for Energy Efficiency, Health Benefit, and Mercury Emissions Reduction Using Heliodon for Physical Modeling. Rochester Institute of Technology.

[10] P Howden, C. (2004). Housing standards: a glossary of housing and health. Epidemiol Community Health, 58, 162-168. https://doi.org/10.1136/jech.2003.011569

[11] Leichter, H. M. (2003). "Evil Habits" and "Personal Choices": Assigning Responsibility for Health in the 20th Century. The Milbank Quarterly, 81(4), 603626. https://doi.org/10.1046/J.0887-378X.2003.00296.X

[12] Cohen, D. A., Farley, T. A., \& Mason, K. (2003). Why is poverty unhealthy? Social and physical mediators. Social Science and Medicine, 57(9), 1631-1641. https://doi.org/10.1016/S0277-9536(03)00015-7

[13] World Health Organization. (1988). Guidelines for Healthy Housing. World Health Organization.

[14] Saniroychansyah, M., Farmawati, A., Anindyah, D. S., \& Atianta, L. (2016). Urban Compactness Effects on the Distributions of Healthy Houses in Yogyakarta City. Procedia - Social and Behavioral Sciences, 227(November 2015), 168-173. https://doi.org/10.1016/j.sbspro.2016.06.058 
[15] Kerinci District Health Office Secretariat. (2015). Healthy Profile of Kerinci District 2015. Kerinci.

[16] Keinci’s Statistic Agency. (2016). Kerinci Regency in Figures. Kerinci.

17] Garg, S., Malik, A., \& Singh, R. (2013). Healthy corporate house means healthy nation. Apollo Medicine, 10(2), 181-184. https://doi.org/10.1016/j.apme.2013.05.004

[18] Hanafiah, K. A. (1991). Rancangan Percobaan; Teori dan Aplikasi. Jakarta: PT Raja Grafindo Persada.

[19] Rendón-Macías, M. E., Villasís-Keever, M. Á., \& Miranda-Novales, M. G. (2016). Descriptive $\quad$ statistics. Revista Alergia Mexico. https://doi.org/10.29262/ram.v63i4.230

[20] Keman, S. (2007). Enam Kebutuhan Fundamental Perumahan Sehat. Jurnal Kesehatan Lingkungan, 3, 183-194

[21] Thomson, H., Petticrew, M., \& Morrison, D. (2001). Health effects of housing improvement: systematic review of intervention studies. BMJ, 323, 187-190

[22] Uy, T. C., Limnirankul, B., \& Chaovanapoonphol, Y. (2015). Factors Impact on Farmers' Adaptation to Drought in Maize Production in Highland Area of Central Vietnam. In Agriculture and Agricultural Science Procedia (Vol. 5, pp. 75-82). Elsevier Srl. https://doi.org/10.1016/j.aaspro.2015.08.011

[23] Place, F., Kariuki, G., Wangila, J., Kristjanson, P., Makauki, A., \& Ndubi, J. (2004). Assessing the factors underlying differences in achievements of farmer groups: Methodological issues and empirical findings from the highlands of Central Kenya. Agricultural Systems, 82(3), 257-272. https://doi.org/10.1016/j.agsy.2004.07.001

[24] Francis Duffy, K. P. (1997). The New Office (Vol. 321). London: Conran Octopus Limited.

[25] Saniroychansyah, M., Farmawati, A., Anindyah, D. S., \& Atianta, L. (2016). Urban 
Compactness Effects on the Distributions of Healthy Houses in Yogyakarta City. Procedia - Social and Behavioral Sciences, 227(November 2015), 168-173. https://doi.org/10.1016/j.sbspro.2016.06.058

[26] Seppanen, Olli Fisk, William J. Faulkner, D. (2008). Cost benefit analysis of the nighttime ventilative cooling in office building. Lawrence Berkeley National Laboratory. https://doi.org/10.1007/978-3-319-46448-0

[27] Lancet, T. (2018). What happened to health in Buenos Aires? The Lancet.com (Vol. 392). Elsevier Ltd. https://doi.org/10.1016/S0140-6736(18)33113-1

[28] Wargocki, P., Sundell, J., Bischof, W., Brundrett, G., Fanger, P. O., Gyntelberg, F., ... Wouters, P. (2002). Ventilation and health in non-industrial indoor environments: Report from a European Multidisciplinary Scientific Consensus Meeting (EUROVEN). Indoor Air, 12(2), 113-128. https://doi.org/10.1034/j.1600$\underline{0668.2002 .01145 . \mathrm{x}}$

[29] Helsinki, I., \& Adviser, S. T. (2012). C3 national building code of finland - Thermal insulation in a building Regulations 2003, (March 1983), 1-7.

[30] FisIAQ. (2010). Classification Of Indoor Environment 2008 Target Values, Design Guidance, and Product Requirements.

[31] Alatas, V., Banerjee, A., Hanna, R., Olken, B. A., \& Tobias, J. (2012). Targeting the poor: Evidence from a field experiment in Indonesia. American Economic Review. https://doi.org/10.1257/aer.102.4.1206

[32] Rush, J. R., \& Peluso, N. L. (1993). Rich Forests, Poor People: Resource Control and Resistance in Java. The Journal of Asian Studies. https://doi.org/10.2307/2059224

[33] Regional Environmental Agency. (2015). Report on the Implementation of Ambient Air Quality Monitoring Equipment in Kerinci Regency and Sungai Penuh City.

[34] Donald K. Milton, P. Mark Glencross, M. D. W. (2000). Risk of Sick Leave Associated with Outdoor Air Supply Rate, Humidification, and Occupant 
Complaints. International Journal Indoor Environment and Health, 10(4), 212-221. https://doi.org/https://doi.org/10.1034/j.1600-0668.2000.010004212.x

[35] Leichter, H. M. (2003). "Evil Habits" and "Personal Choices": Assigning Responsibility for Health in the 20th Century. The Milbank Quarterly, 81(4), 603626. https://doi.org/10.1046/J.0887-378X.2003.00296.X

[36] Bradley, R. P. C., Friend, D. J., \& Gottman, J. M. (2011). Supporting healthy relationships in low-income, violent couples: Reducing conflict and strengthening relationship skills and Satisfaction. Journal of Couple and Relationship Therapy, 10(2), 97-116. https://doi.org/10.1080/15332691.2011.562808

[37] Mirowsky, J., \& Ross, C. E. (1998). Education, personal control, lifestyle and health: A human capital hypothesis. Research on Aging, 20(4), 415-449. https://doi.org/10.1177/0164027598204003

[38] Dursun, B., Cesur, R., \& Mocan, N. (2018). The Impact of Education on Health Outcomes and Behaviors in a Middle-Income, Low-Education Country. Economics and Human Biology, 31, 94-114. https://doi.org/10.1016/j.ehb.2018.07.004

[39] Wilson, A. (2006). Your Green Home; A Guide to Planning a Healthy, Environmentally Friendly New Home. New Society Publisher

[40] American Public Health Association. (2014). National Healthy Housing Standard. American Public Health Association.

[41] Teresko, J. (1996). Public Health Etchics; Key Concepts and Issues Policy and Practice. (A. Dawson, Ed.), Cambridge University Press (I, Vol. 245). Cambridge University Press. https://doi.org/10.1017/CBO9780511862670

[42] World Health Organization. (2011). Guidelines for Drinking-water Quality (Fourth).

[43] World Pumps. (2007). Mobile drive helps solve cloudy water conundrum. Www.Worldpumps.Com, p. 2007. 
[44] Newcombe, C. P. (2003). Impact assessment model for clear water fishes exposed to excessively cloudy water. Journal of the American Water Resources Association, 39(3), 529-544. https://doi.org/10.1111/j.1752-1688.2003.tb03674.x

[45] Vigil, K. M. (1996). Clean Water; An Introduction To Water Q Uality And Water Pollution Control (Secind Edi). United State of America: Oregon State University Press Corvallis.

[46] Schmidt, D., Germano, A. M. C., \& Milani, T. L. (2018). Neuroscience Letters E ff ects of water immersion on sensitivity and plantar skin properties. Neuroscience Letters, 686(June), 41-46. https://doi.org/10.1016/j.neulet.2018.08.048

[47] Kelly, L., \& Whyte, L. (2018). Pathophysiology of diarrhoea. Paediatrics and Child Health, 28(11), 1-7. https://doi.org/10.1016/j.paed.2018.09.002

[48] Nazrul, S., Kamal, M., \& Rahmatullah, R. (2018). Serum zinc levels in children with acute respiratory infections : Association with sociodemography and nutritional status. Clinical Nutrition Experimental, $22,11-18$. https://doi.org/10.1016/j.yclnex.2018.09.002

[49] Kabashima, K., Honda, T., Ginhoux, F., \& Egawa, G. (2019). The immunological anatomy of the skin. Nature Reviews Immunology, 19, 19-30. https://doi.org/10.1038/s41577-018-0084-5

[50] Fairchild, B. D., \& Ritz, C. W. (2009, April). Poultry Drinking Water Primer. The University of Georgia Cooperative Extension, pp. 1-4. 